\title{
Retrofitting urban drainage infrastructure: green or grey?
}

David Dolowitz, Sarah Bell, Melissa Keeley

\begin{abstract}
This paper explores the approaches that London, Glasgow, Washington DC and Philadelphia have taken in responding to urban stormwater and combined sewer overflows challenges. In brief, London has begun construction of a large interceptor tunnel with relatively little attention yet paid to green infrastructure, Philadelphia is pursuing green infrastructure based approaches, and Washington DC and Glasgow are implementing a combination of solutions. The cases illustrate that a diversity of responses are emerging to a common environmental problem in cities around the world.
\end{abstract}

\section{Introduction}

Combined Sewer Overflows (CSOs) are a significant environmental problem for many cities with sewerage infrastructure constructed in the nineteenth and early twentieth centuries. Combined sewers drain both wastewater and surface water and were often deployed as a pragmatic design choice to adapt long-standing surface water drainage networks into waterbased sanitation systems to serve rapidly growing and industrialising cities (Bazalgette, 1865; Beder, 1989; Halliday, 2001; Melosi, 2000). CSOs were intended to prevent sewer flooding during high rainfall events by discharging peak flows directly into local rivers, and have generally increased in frequency since the systems were first installed. Surface water runoff to sewers has increased both because urban surfaces have become more impermeable due to paving and development, and because baseflows of wastewater in sewers have increased due to higher water consumption. The frequency of CSOs is a significant barrier to improving water quality in many major urban rivers around the world. 
While the fundamental cause of CSOs may be similar in cities with similar sewerage systems, responses to the problem vary. 'Green' infrastructure solutions focus on source control of surface water, using techniques such as green roofs, rain gardens, detention basins and infiltration, to prevent or delay runoff into the sewers. 'Grey' infrastructure solutions adapt or expand conventional sewerage networks, including interceptor tunnels to collect CSO discharges before the contaminated water enters the environment. The choice between 'green' or 'grey' infrastructure strategies to prevent CSOs is the outcome of complex political, environmental, technical, economic and social factors. 'Green' infrastructure is often presented as the progressive, sustainable option, while 'grey' infrastructure represents a secure continuation of conventional sewerage design and management.

Interest and adoption of "green" stormwater management approaches is a relatively recent phenomena. During the 1970s the negative impact of CSOs became the focus of environmental campaigning and government regulation in the US and UK (Karvonen, 2011; Novotny et al., 2010). Since then, engineers and urban designers have been developing a range of techniques for managing stormwater at its source in order to reduce the level of urban runoff entering the sewer system. These policies and techniques are variously known as Best Management Practices (BMPs), Low Impact Development (LID) practices, Water Sensitive Urban Design (WSUD), Sustainable (Urban) Drainage Systems (SuDS) and simply as Green Infrastructure..

Trends towards more localised management of stormwater are seen by some as part of a long-term trend towards more sustainable cities. Novotny et al. (2010) identify 5 paradigms 
of urban water management starting with the construction of sewers and moving to the focus on sustainable cities. Brown et al. (2009) trace the movement from a drained city towards the future water sensitive city in Australia. While there is evidence of increasing application of green infrastructure, as we will see, this is not a universal phenomena.

This paper analyses four case studies of cities from the United States and the United Kingdom responding to CSOs with different combinations of green and grey infrastructure. London's Tideway Tunnel project will construct a 30km intercepting sewer underneath the River Thames and expand sewage treatment works. Philadelphia is pursuing a strategy entirely based on green infrastructure and source control of surface water runoff. Glasgow and Washington DC are implementing hybrid strategies combining both green and grey solutions to prevent CSOs. The case studies demonstrate the complexity of decisions in developing strategies for CSO prevention. Factors that emerge as significant in shaping decisions about CSOs include environmental regulation, infrastructure ownership and governance, local leadership and the bio-physical environment. The purpose of the paper is not to promote either green or grey infrastructure solutions to CSOs or other urban environmental problems, but to highlight how local conditions shape apparently technical decisions about urban water infrastructure. The paper begins with a summary of key legislation driving environmental actions in the US, England and Scotland, before analysing the problem and solution to CSOs in each city and finally comparing key factors that shape the particular local responses to a common problem.

\section{Legal frameworks}


The recognition of CSOs as a problem requiring attention and the drivers for action is in part a result of environmental legislation. The responses from cities in the US and the UK are underpinned by the legal framworks in each country, including the role of municipal, state, national and federal regulation and administration.

In England and Scotland the EU Urban Waste Water Treatment (UWWT) Directive of 1991 required states to institute secondary treatment of domestic and mixed wastewater discharges in settlements of more than 2,000 people, and tertiary treatment of wastewater from larger towns and cities in sensitive areas. ${ }^{1}$ The EU Water Framework Directive in 2000 expanded wastewater management to include river basin management. The goal was to achieve 'good status' for all freshwater ecosystems and water bodies by 2015 , followed by a second round of plans for 2015-2021. The Environmental Agency (EA) and the Scottish Environment Protection Agency (SEPA) are responsible for river basin management planning and the enforcement of water quality standards in England and Scotland respectively. It is worth stressing that while all regions of the UK have enacted legislation designed to promote the use of SuDS in new developments; guidance through the planning process has been considerably stronger in Scotland than England (MWH, 2011; ENW, 2013).

In the United States, the core piece of legislation is the 1972 Clean Water Act (CWA) which set a goal that all public waterways should be fishable and swimmable by 1985 (US EPA, 2013; US EPA, 2014a). Despite considerable progress, by the early 1990s over one-third of America's assessed waterways still failed to meet federal water quality standards. In

1 Council Directive 91/271/EEC of 21 May 1991 concerning urban wastewater treatment, http://eurlex.europa.eu/legal-content/EN/TXT/?uri=CELEX:31991L0271, accessed 7 February 2016. 
response, the federal Environmental Protection Agency (EPA) established a more stringent regime in the 1994 National Pollutant Discharge Elimination System (NPDES) permit programme. Among other steps, the NPDES mandated that regulated municipalities had to create and implement Long Term Control Plans (LTCPs), in which a schedule of selected CSO controls had to be set. Municipalities that fail to adequately control CSOs face legal and financial consequences and can be forced to comply with a consent decree - a legally binding agreement for the control of discharge waters. Since the implementation of the NPDES, the EPA has increasingly clarified and supported the use of LID in meeting stormwater requirements. This has led to a small but growing trend amongst cities to begin writing or reopening consent decrees to include significant green infrastructure components (Stoner, 2011; EPA, 2014c).

\section{London}

Greater London is a city of over 8.6 million people, covering 1,572 square kilometres. It is situated on the tidal reach of the River Thames and has an annual average rainfall of $640 \mathrm{~mm}$. London's combined sewerage system is a famous exemplar of nineteenth century engineering (Halliday, 2001). The combined sewer system was originally designed to overflow into the Thames on average four times per year, but CSOs now occur in London more than 50 times per year on average (Bazalgette, 1865; Thames Water, 2012). In 2012, this situation led the European Court of Justice to rule that the UK was in breach of the UWWT Directive in relation to CSOs in London.

London's existing sewerage infrastructure is owned and operated by a private company, Thames Water Utilities Ltd (Thames Water). Investment, pricing, and other business 
operations are regulated by the Office of Water Services (Ofwat), while the Environment Agency (EA) regulates abstraction licencing, discharge permits, flood protection and other environmental activities.

In 2000 Thames Water commissioned the Thames Tideway Strategic Study (TTSS) to set objectives and evaluate options for 'protecting the Thames Tideway from the adverse effects of wastewater discharges' (TTSS, 2005, p.5). It was overseen by a steering committee, chaired by independent engineer Chris Binnie, and included representatives of the EA, the Department of Environment, Food and Rural Affairs (Defra), the Greater London Authority and Thames Water, with Ofwat holding an observer role. SuDS and source control measures were investigated and rejected by the TTTS because of the highly urbanised nature of the catchment, excessive costs, the impermeability of London's clay soils, and the absence of natural receiving waters (due to the incorporation of many of London's original streams and rivers into the sewerage network). The final recommendation of the TTSS was that a $35 \mathrm{~km}$ interceptor tunnel should be built from Hammersmith in west London to the Crossness Sewerage Treatment Works in the Thames Estuary. The estimated cost of the tunnel was $f 1.7$ billion at 2004 prices. The proposal was refined to prioritise CSOs in the River Lee by constructing a separate Lee Tunnel. This reduced the length of the Tideway Tunnel to $30 \mathrm{~km}$, with discharge and treatment at Beckton, the site of existing wastewater treatment works in the east of London.

In 2006, Ofwat commissioned a review of the TTSS study by consultancy firm Jacobs Babtie. The report proposed an alternative strategy of integrated stormwater management, 
including SuDS, two shorter tunnels, separation and real time control of stormwater in sewers, and in-river treatment. This proposal was rejected on the basis that it would not deliver the require reductions in CSOs to meet UWWT Directive requirements.

In 2011 the Thames Tunnel Commission (TTC), funded by five London local authorities most impacted by the tunnel construction, called for a re-evaluation of alternatives, including green infrastructure options, in combination with a smaller tunnel, or no tunnel. The TTC was led by John Palmer, the Earl of Selborne, and members were Jean Venables, pastpresident of the Institution of Civil Engineers, Richard Ashley, Professor of Urban Water at the University of Sheffield, Henry Henderson, Director of the Chicago office of the US Natural Resources Defense Council, and Frans H.M. van de Ven, leader of the Urban Land and Water Management team at the Dutch independent institute for delta technology (Deltares). Submission to the TTC came from local authorities, residents and environmental groups, individual experts and citizens, Thames Water and the relevant regulators and government authorities.

One of the key issues addressed by the report of the TTC was the environmental objectives set by the TTSS to address the problem of CSOs in London. In the absence of specific regulatory standards for urban water quality, the TTCC chose standards to support particular fish species, using dissolved oxygen concentration as a key indicator, as well as public health risk and aesthetic considerations. According to the TTC setting such high environmental standards underpinned the selection of the tunnel as the only viable solution, despite high cost. Alternative strategies, including green infrastructure or a smaller tunnel, were undermined by the difficulty of achieving such 'unrealistic' water quality 
standards (TTC 2011, p. 11). Other issues raised by the TTC against the Tideway Tunnel included questioning forecasts of increasing wastewater baseflow in sewers and the rationale for objectives to achieve improved water quality standards in a relatively short time scale. The TTC highlighted the multiple benefits of $\mathrm{Gl}$ compared with the single function of the tunnel as a solution to CSOs. The TTC noted that the governance and administrative structures for managing water in London undermined efforts towards integrated urban water management:

There is a need to address current planning and funding arrangements for water and wastewater systems, as under these it is easier to construct large, costly, inflexible and environmentally impacting infrastructure systems, like the tunnel, than it is to provide green infrastructure alternatives that deliver many benefits to society and that are adaptable to a changing climate (TTC 2011, p. 3).

In 2013 the Environment Agency (EA) undertook a review to answer the question 'Do we have sufficient evidence and knowledge to be confident that Sustainable Drainage Systems (SuDS) could or could not be reasonably implemented at a scale that achieves the water quality standards for the tidal Thames?' (EA 2013, 3). The report concluded that SuDS alone could not meet UWWTD standards and that the costs, benefits and timeliness of SuDS retrofitting were highly uncertain compared with the tunnel. The EA report highlighted complex institutional arrangements as a barrier to SuDS implementation, referring to a 2011 Ofwat report which compared arrangements for surface water management in England and Wales to other countries (MWH 2011). 
In 2014 Chris Binnie, the original chair of the TTSS steering group, published an independent report opposing the Tideway Tunnel. Binnie claimed that many of the improvements needed to reach the original objectives of the TTSS had been achieved through the construction of the Lee Tunnel and the associated improvements at sewage treatment works, and that implementation of SuDS could significantly reduce storm flows into the sewers. His change of assessment was based on developments in design, data and modelling of SuDS that were not available at the time of the TTSS analysis, and on a reconsideration of assumption about growth in wastewater baseflows. Binnie was particularly critical of the revised cost estimates for the tunnel, which by 2014 had risen to f4.1 billion, compared to the original TTSS estimate of $f 1.7$ billion in 2004 . In 2005 the estimated annual increase in Thames Water customers' bills was $£ 40$, compared a maximum of $£ 80$ in 2015.

Planning permission for the Tideway Tunnel was granted in August 2014. In June 2015 a new private company, Bazalgette Tunnels (operating as 'Tideway'), was formed to construct and deliver the tunnel, with investment risks underwritten by the Treasury. Contracts for construction of four separate sections of the tunnel have been awarded and construction began in 2016.

Despite this large-scale commitment to grey infrastructure, SuDS have since received attention in London as a strategy for surface water management, as a method to relieve pressure on sewers in catchments with limited additional capacity, and for flood resilience. One example is the London Sustainable Drainage Action Plan, produced in partnership between the Mayor of London, Thames Water, Tideway, London Councils and the EA (GLA, 
2015). Thames Water utilise SuDS in particular catchments to address sewer capacity constraints and surface water flooding. Most Local Authorities now recommend SuDS through the development planning process, but enforcement is constrained by the lack of implementation of national policy relating to SuDS and new developments. Thus, while the Tideway Tunnel remains the solution to CSOs, green infrastructure is starting to be promoted for its wider benefits to drainage, flooding and the urban environment.

\section{Glasgow}

The City of Glasgow has a population of 580 thousand people and the wider Glasgow and Clyde Valley metropolitan region has population of 1.5 million. The Greater Glasgow area covers 268 square kilometres along the River Clyde, and receives an annual average rainfall of $1,120 \mathrm{~mm}$. Glasgow began building its underground sewer network between 1850 and 1875. Under the direction of the Glasgow Corporation, over 80 kilometres of pipe were laid to help address pollution and sanitary problems that plagued the city as a result of rapid industrialisation, population growth and the existing system of open sewers. The system was built using a series of intercepting sewers (some based on culverting existing watercourses) that gathered wastewater to be processed at one of three newly constructed wastewater treatment facilities (Dalmarnock, Dalmuir, and Shieldhall), and then discharged into the River Clyde. Glasgow's sewers combine surface and wastewater, and as a result of CSOs the River Clyde and many of its surrounding watercourses have been classified as having 'poor' quality waters according the EU Water Framework Directive.

In response to a major flooding event in 2002 which saw raw sewage deposited in the streets and basements of the city, and the imperatives of implementing the EU Water 
Framework Directive, Glasgow created the 'Glasgow Strategic Drainage Plan - a comprehensive assessment of drainage needs across Glasgow and the surrounding towns' (Adshead 2002, 1). To create this plan and address the city's legacy position of decaying sewers and lack of investment, the city commissioned Hyder Consulting to bring together 'key stakeholders' including Scottish Water, Glasgow City Council, Scottish Environment Protection Agency (SEPA), Scottish Enterprise Glasgow, and subsequently Scottish Water Solutions (a consortium of Scottish Water, other water companies and engineering contractors). The goal of this partnership was not simply to look at gray solutions but to actively promote and find green possibilities to addressing (or helping to address) any future flooding.

The partnership approach that brought together stakeholders and agencies launched with the development of the Drainage Plan was carried forward with the formation of the Glasgow Strategic Drainage Partnership, later expanded and renamed Metropolitan Glasgow Strategic Drainage Partnership (MGSDP). This partnership, led by the Glasgow City Council, brought together relevant local authorities including SEPA, Scottish Water, Scottish Enterprise and British Waterways Scotland (which manages Scottish Canals under contract from the Scottish government). The purpose of the partnership is to find ways to 'upgrade and modernise Glasgow's drainage and sewerage network to reduce flooding and support urban development requirements, while improving water quality and the environment' (MGSDP 2008, 1).

The role of SuDS in managing urban surface water was entrenched in this process by the Water Environment and Water Services (Scotland) Act (2003) (and its subsequent 
amendments), which redefined the term 'sewer' to include SuDS and made Scottish Water responsible for maintenance and replacement of all shared public SuDS. While all parties have a role to play in the development and implementation of SuDS, and the Scottish Government and SEPA encourage all developers to consider the use of SuDS when retrofitting buildings and properties. One of the shortfalls of the 2003 Act is that it only requires Scottish Water to adopt approved SuDS systems, which have been integrated into new developments. Retrofits and non-approved systems remain outside the remit of the Act.

Having a requirement for the integration of SuDS in all new developments, Glasgow has seen a considerable range of SuDS projects completed over the past few years. One of the largest is designed to reduce the effects of storm flooding in South Glasgow. The neighbourhoods of East Renfrewshire, Kirkland Bridge, Kittoch Bridge were selected for SuDS redesign integrating 'flood storage areas...(which would) enhance biodiversity through the creation of artificial wildlife habitats, the creation of woodlands, scrub (lands)... wet grasslands, shallow scrapes, and ponds' (McGowan \& Douglas 2014, 2). The project attenuates the flow of the White Chart, Earn, and Kittoch rivers before their floodwaters reached Glasgow. Significantly, this project was developed under the guidance of a working group of SEPA, Scottish Natural Heritage, Scottish Water, local angling groups and fisheries, RSPB, representatives from three local authorities, and involved active public consultation.

While green infrastructure is an element of Glasgow's stormwater plan, the core of Scottish Water's development plan is the construction of several large storage and conveyance 
tunnels under the city, the largest of which is a three-mile tunnel to run from Queen's Park to Craigton industrial estate. Scottish Water describes the $£ 100$ million project as:

The biggest investment in the network since Victorian times, the upgrade will improve river water quality and the natural environment of the River Clyde and its tributaries, enable the Greater Glasgow area to grow and develop, alleviate sewer flooding and deal with the effects of increased rainfall and climate change. (Scottish Water 2013)

The Scottish Water preference for ponds, basins and large-scale underground storage tunnels is in part due to existing urban infrastructure, soil type and variation in Glasgow's average rainfall. Glasgow is built on a complex mix of soils including: wet mud and sand, boulder clay, solid rock, shale, sandstone, and quicksand. Monthly average rainfall ranges from highs of $130-140 \mathrm{~mm}$ in December and January to lows of $60-65 \mathrm{~mm}$ per month between April and June. As such, while SUDS are recommended or required in many documents, the primary techniques tend not to include infiltration and site-specific practices (as commonly found in the US).

While there is widespread political and industrial support for the implementation and use of SuDS in Scotland, a 2013 report by consulting firm Hydro, 'Engineering Nature's Way', found that of the 151 respondents working in local authorities, SEPA, consulting, homebuilding, contracting and other sectors, $45 \%$ felt that SuDS had only been 'somewhat successful'. This view was explained to be the result of, 'the constraints put in place by Scottish Water and the Local Council as to what they are willing to adopt makes it difficult to use the full range of SuDS features'. More than $84 \%$ of respondents believed that more could be done to 
advance the retrofitting of SuDS in urban areas. One homebuilder noted: 'Whilst there is attention being paid to flood prevention in these areas, very little is being done regarding SuDS'. The problem associated with retrofitting was a belief (held by over $75 \%$ of respondents across all sectors) that there was inadequate funding for the adoption and maintenance of SuDS when considering solutions.

\section{Washington DC}

Washington DC has a population of over 600,000 residents and occupies 158 square kilometres at the confluence of the Anacostia and Potomac Rivers. DC has an average rainfall of $1,160 \mathrm{~mm}$ and sits in the heart of the Chesapeake Bay watershed, which is currently threatened by hypoxia and eutrophication, despite significant efforts by DC and other watershed stakeholders to address the situation (Boesch et al. 2001; Chesapeake Bay Program, 1987; National Research Council 2008)..

As the capital city, DC has operated under direct federal control or oversight and the federal government owns $40 \%$ of land, including much of that immediately adjacent to the district's major water bodies (Chesapeake Bay Program 1996). The District of Columbia Water and Sewer Authority (DC Water) manages combined sewers and the Blue Plains sewage treatment plant and its finances are not tied to DC's overall budget (DC Water 2012b; DC Water ndd). The District of Columbia Department of the Environment (DDOE) is also integrally involved through management of separate storm sewers and the management and regulation of DC's waters. 
DC's over 60 CSO outfalls (triggered by rain events as little as $2.5 \mathrm{~mm}$ ) continue to be a major source of impairment for receiving waters (DC Water 2002). In response to legal suits for Clean Water Act Violations, and under a 2005 consent decree, DC Water created the 'Clean Rivers Project,' Long Term Control Plan (LTCP) (US District Court for DC 2003). This plan is designed to reduce CSO overflow volumes in the city by $96 \%$ to an estimated $138 \mathrm{mg} / \mathrm{avg} \mathrm{yr}$ at an estimated cost of \$2.6 Billion (2001 dollars) (DC Water, 2012b; DC Water, 2014b).

The plan originally featured the creation of four storage and conveyance tunnels and $\$ 3$ million devoted to LID retrofits, largely in the form of demonstration projects (DC Water 2012b). Reasons the initial plan did not include more Gl are: lack of information; the high rate of CSO reductions required; and short timetable for improvements (Ray 2014). The last two considerations were particularly acute in DC, perhaps because of DC's location in the sensitive and polluted Chesapeake Bay watershed.

While grey infrastructure was a component of DC Water's original LTCP, other city agencies have also encouraged the use of green infrastructure through a variety of policy and planning instruments, designed to address broader water quality issues. For instance, DDOE's RiverSmart Homes program provides consultation and subsidies to property owners for onsite stormwater management (DDOE ndb). In 2010 DDOE and DC Water began to assess stormwater removal fees tiered to impervious area (DDOE, ndc; DC Water nde). In 2013 DDOE released guidelines requiring all new construction greater than 465 square metres to retain the first $30 \mathrm{~mm}$ of rainfall or to combine on-site and off-site retention through their Stormwater Credit Trading programme (DDOE 2013). In 2013, the DC Department of Planning instituted the Green Area Ratio, a planning instrument that requires 
all new development and significant renovation projects to incorporate green landscape elements (DDOE 2014).

Several converging trends led to the reopening of DC's consent decree in 2014 to include a significant green infrastructure requirement. First, a significant increase in information about green infrastructure related stormwater benefits and financial costs have emerged. In addition, the EPA has clarified and supported the role of green infrastructure in meeting regulatory requirements (Casey Trees). There were also changes in DC Water. Amongst these was the 2009 decision to hire George Hawkins as CEO and General Manager, a man with a background as an environmental advocate, director of the DDOE, and chair of the $\begin{array}{llll}\text { committee to develop } & \text { to s s stainability }\end{array}$ (http://www.dcwater.com/about/hawkins.cfm). Finally, around this time, the financial implications of the current consent decree became increasingly clear. Of particular concern was the effect of rising sewerage rates on low-income residents (DC Water 2014b; Ray 2014).

In 2016, the Long Term Control Plan Modification for Green Infrastructure was officially accepted. This plan fully replaces one of four newly planned CSO interceptor tunnels with a green infrastructure investment of $\$ 90$ million, addresses overflows to the Potomac through a combination of grey-green infrastructure, and gives the city an additional five years to complete the project (DC Water 2014b). DC Water justifies this change citing added social, environmental and economic benefits, reduced financial impact on ratepayers, and synergy with the Mayor's Sustainable DC Plan (DC Water 2014b; DDOE nd). While community and advocacy groups generally support the inclusion of green infrastructure, concerns about the 
plan have also been articulated. These include: 1) the effects/necessity of delays in the timetable relative to the initial LTCP; 2) accountability being tied to budget spent on green infrastructure rather than environmental outcomes; 3) insufficiently articulated maintenance and repair costs and protocols, and 4) the unfortunate clustering of green infrastructure projects within the city-significantly not occurring in some of the poorest communities neighbouring the Anacostia River (NRDC, nd; Chavez, 2014; Fellows, 2014).

\section{Philadelphia}

Philadelphia is the sixth largest US city, with a population of over 1.5 million (down from a peak of 2 Million in the 1950s) within its 347 square kilometres. Philadelphia is particularly diverse, with over $44 \%$ of its population identifying as African American, but faces challenges with $26 \%$ of residents living below the poverty level (US Census Bureau 2012). Despite high levels of poverty, in many ways Philadelphia has been a pioneer in water management. It was the first US city to take on water supply as a municipal responsibility in 1801 and later created the 45-hectare Fairmount Park in the middle of the city to protect the city's water supply (City of Philadelphia nd). The Philadelphia Water Department (PWD) was created in the 1950 s as a municipally owned and financed department, to manage drinking water and wastewater services. Currently, the PWD maintains three wastewater treatment plants and nearly $4,828 \mathrm{~km}$ of sewers (60\% of which are combined) within the city and neighbouring 596 square km of suburbs (Holst 2007). Philadelphia receives about $1,043 \mathrm{~mm}$ of precipitation per year and has well-drained soils, yet-due to development on historic tidal marsh-experiences flooding and subsidence in some areas (PWD 2009). 
Several developments paved the way for Philadelphia's current approach to stormwater management. First, the region has been influenced by planning and landscape practitioners who trained with The University of Pennsylvania's Ian McHarg (raised in Glasgow), whose 1969 book Design with Nature is the cornerstone text developing the concept of ecological planning. Second, de-industrialisation challenges, particularly abandoned properties and vacant lots have galvanised and unified many non-profit organisations and city agencies for over 20 years (Pennsylvania Horticultural Society 1995; City of Philadelphia nd). Third, PWD has a long history of thinking of land-water interconnections within its system and of regional watershed management. Led by Howard Neukrug, the PWD developed the Office of Watersheds in 1999 to better address the formerly separate operations of CSO management, stormwater management and source water control watershed-wide (PWD 2009). Crucially, that Office defined its mission broadly, stating, 'government agencies (must) break out of their traditional roles of providing narrowly defined services' (City of Philadelphia 2011).

In order to comply with the federal Clean Water Act, PWD first examined the costs and benefits of various CSO management options utilising a 'Triple Bottom Line' assessment methodology (Stratus Consulting 2009). This approach compared costs of potential projects that included an assessment of wider social, economic and environmental benefits of each option. In this report, green infrastructure compared favourably to grey alternatives primarily due to non-water-related benefits including reductions in heat-stress mortality, improved aesthetics and property value, and increased recreational opportunities (Maimone et al. 2011). 
Based on these findings, in 2009, the PWD created a green infrastructure-based Long Term Control Plan which, as 'the single largest investment in the City's environment over the next 25 years...presents a unique opportunity to be much more than just a water quality improvement program.' Philadelphia's 'Green City, Clean Waters' plan sets out an agenda spending \$2.4 billion between 2011-2026, 67\% of which will be spent on green infrastructure techniques (DeGood 2013). As such, it is a commitment to reshape the city (US Housing and Urban Development 2013) by developing 'the most extensive urban network of green infrastructure in the United States', and using Philadelphia's vacant land as a resource (Natural Resources Defense Council nd).

This plan has since been formalised through a Consent Decree and Partnership Agreements with the EPA and state authorities (EPA 2015). The objective is to create 9,500 'Greened Acres' over 25 years. That is, to convert nearly $40.5 \mathrm{~km}^{2}$ of impermeable surfaces to manage $25 \mathrm{~mm}$ of runoff onsite and reduce overflows by $85 \%$ through projects on both public and private property (Maimone et al. 2011; Water Environment Federation 2014). The city owns approximately $45 \%$ of impervious surfaces within the CSO area and will integrate green infrastructure into capital improvement projects on city-owned streets, sidewalks, and properties. Other public land projects include a large-scale street tree planting programme; preserved open space-including dedication of vacant and abandoned lands, and stream restoration (City of Philadelphia 2011; US Housing and Urban Development 2013).

The PWD has created requirements and incentives for green stormwater management on private property; including rain gardens, green roofs, street trees, porous pavers, and other green interventions. Beginning in 2010, the PWD adopted a parcel-based billing system for 
commercial properties. These assess fees in proportion to the amount of impervious surface. A geographical information system (GIS) supports this programme so that property owners can view information about their parcel's imperviousness online (Cunningham 2011). In addition to greater equitability, this system encourages green retrofits (Valderrama et al. 2012). Grant programmes also provide technical and financial assistance and encourage project aggregation for commercial property owners (Valderrama et al. 2013; PWD 2015). As of June 2014-five years into the 25-year planning period-the city had created $1.3 \mathrm{~km}^{2}$ of newly pervious area (City of Philadelphia 2014).

\section{Discussion}

Comparing different responses to CSOs in four cities reveals key factors influencing urban environmental decision-making, summarised in Table 1.

Table 1. Comparing responses to Combined Sewer Overflows in Four Cities

\begin{tabular}{|c|c|c|c|c|}
\hline & London & Glasgow & Washington DC & Philadelphia \\
\hline Environment & $\begin{array}{l}\text { Mostly clay soils. } \\
640 \text { mm annual rainfall, } \\
\text { evenly distributed. } \\
\text { More intense storms } \\
\text { predicted. } \\
\text { Rivers Thames and Lee } \\
\text { receiving CSOs, poor } \\
\text { water quality. } \\
\text { Dense urban form. }\end{array}$ & $\begin{array}{l}\text { Mixed Soils. } \\
1,120 \mathrm{~mm} \text { annual } \\
\text { rainfall, unevenly } \\
\text { distributed. More } \\
\text { intense storms } \\
\text { predicted, River Clyde } \\
\text { receiving CSOs, rated } \\
\text { poor water quality. } \\
\text { Dense urban form. }\end{array}$ & $\begin{array}{l}\text { 1,160mm annual } \\
\text { rainfall, evenly } \\
\text { distributed. } \\
\text { Within sensitive and } \\
\text { degraded Chesapeake } \\
\text { Bay watershed. Dense } \\
\text { urban form. }\end{array}$ & $\begin{array}{l}\text { Well drained soils. } \\
1,055 \mathrm{~mm} \text { annual } \\
\text { rainfall, evenly } \\
\text { distributed. } \\
\text { Development on } \\
\text { historic tidal wetlands. } \\
\text { Subsidence problems. } \\
\text { Dense urban form and } \\
\text { vacant land problem. }\end{array}$ \\
\hline Regulation & $\begin{array}{l}\text { EU UWWT Directive. } \\
\text { Limited national } \\
\text { guidance or drivers for } \\
\text { SuDS. }\end{array}$ & $\begin{array}{l}\text { EU UWWT Directive. } \\
\text { Consistent national } \\
\text { support for SuDS. }\end{array}$ & $\begin{array}{l}\text { Clean Water Act. } \\
\text { Additional water quality } \\
\text { requirements given } \\
\text { location in Chesapeake } \\
\text { Bay watershed. }\end{array}$ & Clean Water Act. \\
\hline Governance & $\begin{array}{l}\text { Private ownership of } \\
\text { infrastructure. } \\
\text { EU Directives. } \\
\text { Local government } \\
\text { jurisdiction uncertain. }\end{array}$ & $\begin{array}{l}\text { Public ownership of } \\
\text { infrastructure via } \\
\text { Scottish Water. } \\
\text { EU Directives. } \\
\text { Range of Scottish Acts } \\
\text { and building } \\
\text { regulations. }\end{array}$ & $\begin{array}{l}\text { DC water is } \\
\text { independent authority } \\
\text { of DC. } \\
\text { DDOE manages MS4s } \\
\text { and responsible for } \\
\text { receiving water quality. } \\
\text { Federal ownership of } \\
40 \% \text { of land area. }\end{array}$ & $\begin{array}{l}\text { PWD is municipally } \\
\text { owned and financed. }\end{array}$ \\
\hline Economics & $\begin{array}{l}\text { Regulated monopoly, } \\
\text { funded through water }\end{array}$ & $\begin{array}{l}\text { Regulated monopoly, } \\
\text { funded through water }\end{array}$ & $\begin{array}{l}\text { Funded through user } \\
\text { fees, grants and bonds. }\end{array}$ & $\begin{array}{l}\text { Funded through user } \\
\text { fees, grants and bonds. }\end{array}$ \\
\hline
\end{tabular}




\begin{tabular}{|c|c|c|c|c|}
\hline & $\begin{array}{l}\text { bills. } \\
\text { Private capital } \\
\text { investment. } \\
\text { High land values. }\end{array}$ & $\begin{array}{l}\text { rates. } \\
\text { Mixed land values. }\end{array}$ & $\begin{array}{l}\text { DC Water's finances are } \\
\text { not tied to } D^{\prime} \text { 's overall } \\
\text { budget. }\end{array}$ & \\
\hline Society & $\begin{array}{l}\text { Resistance to tunnel } \\
\text { from some engineers, } \\
\text { local authorities and } \\
\text { environmental NGOs. } \\
\text { Little wider } \\
\text { engagement with CSOs } \\
\text { and tunnel beyond } \\
\text { communities impacted } \\
\text { by construction. } \\
\text { Recreational water } \\
\text { users in favour of } \\
\text { tunnel. }\end{array}$ & $\begin{array}{l}\text { Most feel more could } \\
\text { be done to retrofit } \\
\text { SuDS. A majority } \\
\text { believes more should } \\
\text { be done in the upkeep } \\
\text { of SuDS systems. Most } \\
\text { believe legislation has } \\
\text { been why Scotland is } \\
\text { ahead of England and } \\
\text { Wales in the } \\
\text { implementation of } \\
\text { SuDS. }\end{array}$ & $\begin{array}{l}\text { Great income disparity } \\
\text { (nearly } 20 \% \text { of DC } \\
\text { households live in } \\
\text { poverty). } \\
\text { Some resistance to GI } \\
\text { among those with a } \\
\text { focus on environmental } \\
\text { justice. Focus on water } \\
\text { quality in Chesapeake } \\
\text { Bay. }\end{array}$ & $\begin{array}{l}\text { High levels of } \\
\text { unemployment, } \\
\text { poverty, and property } \\
\text { vacancy. } \\
\text { Many agencies and } \\
\text { non-profits, which have } \\
\text { cooperated to manage } \\
\text { vacancy problems. } \\
\text { Local emphasis on } \\
\text { ecologically sensitive } \\
\text { planning. }\end{array}$ \\
\hline Leadership & $\begin{array}{l}\text { Thames Water and } \\
\text { regulators in agreement } \\
\text { about tunnel solution. }\end{array}$ & $\begin{array}{l}\text { Multi-stakeholder } \\
\text { partnerships. }\end{array}$ & $\begin{array}{l}\text { New management- } \\
\text { George Hawkins-leads } \\
\text { in new direction; } \\
\text { background in } \\
\text { environmental } \\
\text { advocacy and } \\
\text { sustainability. }\end{array}$ & $\begin{array}{l}\text { Howard Neukrug and } \\
\text { Water Department as } \\
\text { regional leader. }\end{array}$ \\
\hline
\end{tabular}

Local environmental conditions such as rainfall, receiving water quality, soil type, climate change forecasts and urban density influence the technical feasibility of different options. For instance, London's clay soils and high density urban form were a point of contention as proponents of the tunnel claimed that they constrained opportunities for infiltration and local storage of stormwater, while Philadelphia's well drained soils and areas of abandoned land made green infrastructure solutions more feasible. Further, Washington DC's location in a sensitive and tightly-regulated watershed-the Chesapeake Bay-has resulted in that city facing much higher requirements for CSO overflow volumes reduction than other US cities. This means that DC must control larger storm events than Philadelphia, for example, and large storm events are harder to control with green infrastructure than small and medium sized events. Oponents of the Tideway Tunnel in London contested the high environmental objectives set by the Thames Tideway Strategic Study as leading to an unnecessarily high cost solution focussed only on water quality to the detriment of wider environmental benefits of green infrastructure. 
The governance of urban drainage infrastructure, including ownership, planning and regulation, influences decision making about responses to CSOs. London was unique of the four case study cities in that its drainage, sewerage and wastewater infrastructure are privately owned. The decision-making process in London involved a range of stakeholders and was highly scrutinised by government agencies and independent regulators. However, the separation between privately owned infrastructure and public responsibility for urban planning in London is less conducive to institutional integration and flexibility, which was evident in cities that placed greater emphasis on green infrastructure solutions. Municipally focused responses to CSOs in the two US based case studies enabled the implementation of a wider range of planning and regulatory instruments to promote green infrastructure than in the UK cases, especially London. Philadelphia, the only city in our sample to focus entirely on green infrastructure, chose this option primarily based on assessments of the non-water benefits to their community. Crucially, its public water department was able to define its mission broadly, breaking with traditions of more narrowly defined service provision.

While both the UK and US have regulations surrounding CSO abatement, this is another point of difference. In the US, there is intense legal pressure to manage CSOs, through the development of legally-binding Long Term Control Plans. While these plans are required, the approach to CSO abatement is not proscribed. The regulatory environment in the US is increasingly open to green infrastructure, but most US cities have implemented LTCPS emphasizing "grey" infrastructure strategies, often setting aside some funds for green infrastructure demonstration projects. In this context, DC is now a part of a small but growing number of US cities to integrate green infrastructure more substantively into its 
LTCP, and Philadelphia is the only US city we are aware of that has utilized a CSO abatement approach based primarily on green infrastructure.

The economic context of each city and the ownership of its infrastructure influenced the viability of different options for reducing CSOs. Private ownership, secure income through regulated water charging, and central government underwriting as a project of national importance, provide a structure for capital investment for the interceptor tunnel in London. By contrast, municipal governments in DC and Philadelphia are highly constrained in their ability to raise capital and increase sewer charges, providing a driver for less capitalintensive green infrastructure solutions.

Social drivers in decision-making about drainage are evident in the integration of green infrastructure into urban regeneration planning for post-industrial Glasgow and Philadelphia. Environmental justice concerns about the impact of CSOs on poor neighbourhoods compared to the benefits of green infrastructure in wealthier neighbourhoods have shaped debate in Washington DC. Social engagement in London has mostly been limited to protests by residents and local politicians in boroughs most impacted by the construction of the tunnel, and support by recreational users of the river.

The role of strong local leaders in making the case for green infrastructure solutions was evident in Philadelphia, Washington DC, and Glasgow but notably absent in London. In London the main proponents of SuDS solutions were outside Thames Water and key regulators and decision makers, and were therefore positioned as opponents to the tunnel. In Glasgow and the US cities, strong individual leaders within the water utilities and city 
government were able to demonstrate the wider values of green infrastructure and achieve change across institutions by linking to broader environmental and sustainability objectives despite some uncertainty about green infrastructure implementation at scale and related costs, including maintenance.

\section{Conclusion}

Combined sewers represented a standard engineering response to nineteenth century public health crises, but responses to the problem of CSOs in the twenty-first century are more divergent. In the US, legal action is requiring cities to rapidly address CSO problems through the development of long term control plans, some of which include green infrastructure solutions. Local environmental, economic, political and social conditions are shaping technical decisions about how to solve CSOs. Comparing London, Glasgow, Washington DC and Philadelphia shows that the choice of 'green' or 'grey' solutions is highly dependent on diverse factors such as access to capital investment, institutional flexibility, local leadership regulatory frameworks, and urban social context. Technical constraints also contribute to grey and green infrastructure choice.

As post-industrial cities follow different economic, social and political pathways, their infrastructural choices are also diverging. Green infrastructure solutions are more viable in Glasgow, Washington DC and Philadelphia where drainage infrastructure is still publically owned and a wider range of policy instruments are used to promote sustainable and decentralised solutions. An interceptor tunnel was more viable in London where the institutional, economic and regulatory structure of the water industry supported large 
capital investment. While proponents of green infrastructure frame these solutions within narratives of progress towards urban sustainability, the complexity of urban development and infrastructure governance means that this may not be the next paradigmatic, universal response to urban drainage challenges. 


\section{References}

Adshead H (2002). Glasgow's Strategic Drainage Plan: dealing with the legacy and providing for the future. Available at: http://waterprojectsonline.com/case studies/2006/Scottish\%20Glasgow\%20Drainage\%202006 .pdf (accessed 16 March 2016).

Bazalgette J (1865) On the main drainage of London, and the interception of the sewage from the River Thames, In Howie Wand Chrimes M (eds.) (1987) Thames Tunnel to Channel Tunnel Thomas Telford Ltd: London, pp.107-149.

Beder S (1989) Toxic fish and sewer surfing. Sydney: Allen and Unwin.

Brown R, Keath N and Wong T (2009) Urban water management in cities: historical, current and future regimes. Water Science and Technology 59 (5): 847-855.

Chavez J (2014) Draft Proposed Long Term Control Plan Modification for Green Infrastructure. Report. Available at: http://www.potomacriverkeeper.org/sites/default/files/attachments/earthjustice_et_a I_comment_final_dc_cso_green_infrastructure_4-14-14.pdf (accessed 30 September 2014).

Chesapeake Bay Program (1987) 1987 Chesapeake Bay Agreement. Available at: http://www.chesapeakebay.net/content/publications/cbp_12510.pdf (Accessed 30 September 2014).

Chesapeake Bay Program (1996) Special Tributary Strategy for Federal Lands in the District of Columbia Available at: http://www.chesapeakebay.net/content/publications/cbp_12515.pdf (Accessed 30 September 2014).

City of Philadelphia (2011). The City of Philadelphia's Program for Combined Sewer Overflow Control Program Summary. Available at: http://www.phillywatersheds.org/doc/GCCW AmendedJune2011 LOWRES-web.pdf. (accessed XXXX)

City of Philadelphia (2014). Greenworks Philadelphia: Progress Report. Available at: http://www.phila.gov/green/PDFs/Greenworksprogressreport.pdf. (accessed XXXXX)

City of Philadelphia (nd). Vacant Lot Program. Available at: http://www.phila.gov/qualityoflife/vacantlotprogram/Pages/default.aspx. $\quad$ (accessed 15 March 2016).

City of Philadelphia (nd). Brief History of the Philadelphia Water Department. Available at: http://www.phila.gov/water/educationoutreach/Documents/PWD History.pdf. (accessed 12 March 2016).

City of Philadelphia (nd). Greenworks Philadelphia: Executive Summary. Availalbe at: http://www.phila.gov/green/greenworks/pdf/GreenworksExecSummary.pdf. (accessed 1 February 2016)

City of Philadelphia (nd). Non-Residential Stormwater Billing. Available at: http://www.phila.gov/water/wu/stormwater/Pages/NonResidentialStormwaterBilling.aspx. (accessed xxxx)

Cunningham C (2011). GIS For Green. Storm Water Solutions. Available at: http://www.estormwater.com/gis-green. (accessed 15 March 2016).

DC Water (2002) WASA's Recommended Combined Sewer System Long Term Control Plan.Available at: https://www.dcwater.com/workzones/projects/pdfs/ltcp/Control_Plan_Highlights.pdf (accessed 30 September 2014). 
DC Water (2012a) Green Infrastructure Partnership Agreement.. Available at: http://www.epa.gov/reg3wapd/pdf/pdf_chesbay/GreenPartnshipAgreement.pdf (Accessed 30 September 2014).

DC Water (2012b). WASA's Recommended Combined Sewer System Long Term Control Plan. Available http://www.dcwater.com/workzones/projects/pdfs/ltcp/Executive_Summary.pdf (accessed 30 September 2014).

DC Water(2014a). Lady Bird Advances Video, Government of the District of Columbia. Available at: http://www.youtube.com/watch?v=J5oEqtpB1go (accessed 30 September 2014).

DC Water (2014b). Long Term Control Plan Modification for Green Infrastructure, Available at:

http://www.dcwater.com/education/gi_challenge_images/gi_public_comment_draft.p df (accessed 30 September 2014).

DC Water (ndb). Combined Sewer System, Available at: http://www.dcwater.com/wastewater_collection/css/ (accessed 30 September 2014).

DC Water, ndc. Facilities, Available at: http://www.dcwater.com/about/facilities.cfm (Accessed 30 September 2014).

DC Water (ndd). History of Sewer System, Available at: http://www.dcwater.com/wastewater_collection/history.cfm (Accessed 30 September 2014).

DC Water (nde). Impervious Area Change, Available at: http://www.dcwater.com/customercare/iab.cfm (Accessed 30 September 2014).

DeGood K (2013). Clean Water Infrastructure The Cost of Inaction. Center for American Progress. Available at: https://www.americanprogress.org/issues/economy/report/2013/11/04/78526/cleanwater-infrastructure (accessed 15/3/2016).

District Office of the Environment (DDOE), (2013). Stormwater Management, and Soil Erosion and Sediment Control Available at: http://ddoe.dc.gov/sites/default/files/dc/sites/ddoe/page_content/attachments/2013 \%20SW\%20Rule.pdf (accessed 30 September 2014).

District Office of the Environment (DDOE), (2014). Green Area Ratio online. Washington DC: Government of the District of Columbia. Available at: http://green.dc.gov/sites/default/files/dc/sites/ddoe/service_content/attachments/GA RGuidebook_03_13_2014.pdf (accessed 30 September 2014).

District Office of the Environment (DDOE) (nda). Changes to the District's Stormwater Fee online. Washington, DC: Government of the District of Columbia, Available at: http://green.dc.gov/service/changes-districts-stormwater-fee (accessed 30 September 2014).

District Office of the Environment (DDOE) (ndb). RiverSmart Homes - Overview, Available at: http://ddoe.dc.gov/service/riversmart-homes-overview (accessed 30 September 2014).

District Office of the Environment (DDOE) (ndc). RiverSmart Rewards and Clean Rivers IAC Incentive Programs, Available at: http://green.dc.gov/riversmartrewards (accessed 30 September 2014).

District Office of the Environment (DDOE) (nde). Sustainable DC Plan, Available at: http://sustainable.dc.gov/sites/default/files/dc/sites/sustainable/page_content/attach ments/SDC\%20Final\%20Plan.pdf (accessed 30 September 2014). 
Engineering Nature's Way (ENW) (2013). SUDS in Scotland - Experience and Opportunity. Hydro International, Available at: http://www.engineeringnaturesway.co.uk/wpcontent/uploads/2013/11/ENW-SUDS-in-Scotland.pdf (accessed 12 February 2016).

Environment Agency (EA) (2013) An assessment of evidence on Sustainable Drainage Systems and the Thames Tideway Standards. Available at: http://webarchive.nationalarchives.gov.uk/20140328084622/http:/www.environmentagency.gov.uk/static/documents/Research/SuDS and the Thames Tunnel Assessmen t Final Report Oct 2013.pdf (accessed 20 April 2016).

Fellows A (2014). Comments on DC Water Green Infrastructure Program. Available at: http://www.cleanwateraction.org/publication/comments-dc-water-green-

infrastructure-program (accessed 30 September 2014).

Greater London Authority (GLA) (2015) London Sustainable Drainage Action Plan - draft for public consultation. Available at:

https://www.london.gov.uk/sites/default/files/Isdap final.pdf (accessed 20 April 2016).

Halliday S (2001). The Great Stink of London. Stroud, Sutton Publishing Ltd.

Holst A (2007). The Philadelphia Water Department and the Burden of History. Public Works Management \& Policy 11(3): 233-238.

Karvonen A (2011). Politics of Urban Runoff Cambridge. MA: MIT Press.

Kleidorfer M, Moderl M, Sitzenfrei R, Urich C and Rauch W (2009). A case independent approach on the impact of climate change effects on combined sewer system performance. Water Science and Technology. 60(6) 1555-1563.

Maimone M, O'Rourke D E, Knighton J O and Thomas C P (2011). Potential Impacts Of Extensive Stormwater Infiltration In Philadelphia. Environmental Engineer: Applied Research and Practice. (14). Available at: http://www.aaees.org/downloadcenter/EESAppliedResearchandPracticeV14P1.pdf (accessed 15/3/2016)

Melosi M (2000). The sanitary city. Baltimore: The Johns Hopkins University Press.

McGowan Douglas (2014). White Chart Water Flood Prevention Scheme. Available at: http://www.waterprojectsonline.com/case studies/2013-

Virtual/Glasgow White Cart 2013 VE.pdf (accessed 3 March 2015).

MGSDP (2008). Briefing Note 1. Glasgow: MGSDP.

MWH (2011). Comparing the Arrangements for the Management of Surface Water in England and Wales to Arrangements in Other Countries. Available at: http://webarchive.nationalarchives.gov.uk/20150624091829/http://ofwat.gov.uk/futur e/sustainable/drainage/rpt com 201102mwhswd.pdf (accessed 7 February 2016).

Natural Resources Defense Council (nd). Philadelphia, Pennsylvania Rooftops to Rivers II. Available at: http://www.nrdc.org/water/stormwater/files/RooftopstoRivers Philadelphia.pdf (accessed 15 March 2016)

Novotny V, Ahern J and Brown P (2010). Water Centric Sustainable Communities. Hoboken NJ: Wiley

O'Connell J. (2010). Federal Government Refuses to Pay D.C. Stormwater Fee. Washington DC: The Washington Post. Available at: http://www.washingtonpost.com/wpdyn/content/article/2010/10/15/AR2010101505997.html (accessed 30 September 2014).

Pennsylvania Horticultural Society (1995). Urban Vacent Land; Issues and Recommendations. Report for the Pennsy/vania Horticultural Society, September. 
(PWD) Philadelphia Water Department (2009). Philadelphia Combined Sewer Overflow Long Term Control Plan Update. Available at: http://www.phillywatersheds.org/ltcpu/Vol05 Precip.pdf (accessed 15 March 2016).

(PWD) Philadelphia Water Department (2015). Greened Acre Retrofit Program. Available at: http://www.phillywatersheds.org/category/blog-tags/greened-acre-retrofit-program (accessed 3 February 2015)

Ray C (2014). DC Water Renegotiates Clean River's Program to Enhance Green Infrastructure Investments. Available at: http://www.wetweatherpartnership.com/wpcontent/uploads/sites/9/2014/05/Ray-C.-DC-Water-Renegotiates-Clean-RiversProgram-to-Enhance-Green-Infrastructure-Investments.pdf (accessed 30 September 2014).

Reps J (1956). William Penn and the Planning of Philadelphia. The Town Planning Review. 27(1): 27-39.

Scottish Water (2013). Massive waste water tunnel for Glasgow. Available at: http://www.scottishwater.co.uk/business/about-us/media-centre/newsarchive/massive-waste-water-tunnel-for-glasgow. (accessed 12 February 2016).

Stoner N (2011). Protecting Water Quality with Green Infrastructure in EPA Water Permitting and Enforcement Programs. Available at: http://water.epa.gov/infrastructure/greeninfrastructure/upload/gi_memo_protectingw aterquality.pdf (accessed 30 September 2014).

Stratus Consulting (2009). A Triple Bottom Line Assessment of Traditional and Green Infrastructure Options for Controlling CSO Events in Philadelphia's Watersheds. Available at: https://www.michigan.gov/documents/dnr/TBL.AssessmentGreenVsTraditionalStormw aterMgt 293337 7.pdf (accessed 15 March 2016).

Thames Water (2012). Why does London need the Thames Tideway Tunnel. Available at: https://www.thameswater.co.uk/london-tideway-improvements-the-case-for-thethames-tunnel.pdf (accessed 7 February 2016).

Thames Tideway Strategic Study (TTSS) (2005). Steering Group Report. Available at: https://infrastructure.planninginspectorate.gov.uk/wpcontent/ipc/uploads/projects/WW010001/2.\%20PostSubmission/Application\%20Documents/Other\%20Documents/8.1.2 Thames Tideway Strategic Study Steering Group Report.pdf (accessed 20 April 2016).

US Census Bureau (2012). State \& County Quick Facts: Philadelphia County, Pennsylvania. Available at: http://quickfacts.census.gov/qfd/states/42/42101.html.

US Housing and Urban Development (2013). Green Infrastructure Aims to Reshape Philadelphia. Available

at: http://archives.huduser.org/scrc/sustainability/newsletter 040113 1.html (accessed 12 March 2016)

US District Court for the District of Columbia (2003). Consent Decree. Available at: http://www2.epa.gov/sites/production/files/documents/dcwasa-cd.pdf (accessed 30 September 2014).

US Environmental Protection Agency (EPA) (2013). A Brief Summary of the History of NPDES. Available at: http://www.epa.gov/region1/npdes/history.html (accessed 30 September 2014). 
US Environmental Protection Agency (EPA) (2014a). CSO Control Policy. Available at: http://water.epa.gov/polwaste/npdes/cso/CSO-Control-Policy.cfm (accessed 30 September 2014).

US Environmental Protection Agency (EPA) (2014b). Permits Issued by the Mid-Atlantic Region. Available at: http://www.epa.gov/reg3wapd/npdes/dcpermits.htm (accessed 30 September 2014).

US Environmental Protection Agency (EPA) (2014c). Policy Memos and MOUs. Available at: http://water.epa.gov/infrastructure/greeninfrastructure/gi_support.cfm\#PolicyMemos (accessed 30 September 2014).

Van Wye B (2012). Making Stormwater Retrofits Pay. Available at: http://chesapeakestormwater.net/wp-content/uploads/downloads/2012/08/Makingstormwater-retrofits-pay-Aug12.pdf (accessed 30 September 2014).

Valderrama A, Levine I, Yeh S and Bloomgarden E (2012). Financing Stormwater Retrofits in Philadelphia and Beyond. Available at: http://www.nrdc.org/water/files/stormwaterfinancing-report.pdf (accessed 10 March 2015)

Valderrama A, Levine L, Bloomgarden E, Bayon R, Wachowicz K and Kaiser C (2013). Creating Clean Water Cash Alows. Available http://www.nrdc.org/water/stormwater/files/green-infrastructure-pa-report.pdf.

Water Environment Federation (2014). Innovative Financing Accelerates Stormwater Management. Available at: http://stormwater.wef.org/2014/09/innovative-financing (accessed 19 March 2015)

Weigley, R.F. (1982) Philadelphia: a 300-year History. New York: W.W. Norton \& Company. 